\title{
"Jonas, derefter Katrine og Sebastian" - en enkel metode til at lære alle de studerendes navne
}

\author{
Anker Helms Jørgensen, lektor, Innovation og kommunikation, IT Univer-
} sitetet i København.

\begin{abstract}
Denne artikel præsenterer en enkel, systematisk metode til at lære alle de studerendes navne i universitetsundervisning. Metoden er ret effektiv: I sidste semester lærte forfatteren 30 studerendes navne på 1,5 time; det svarer til 3 minutter pr. studerende og 6 minutter pr. uge. Erfaringen viser, at dette virker fremmende på undervisningsmiljøet. Dette blev bekræftet af en empirisk undersøgelse: De studerende føler sig velkomne, anerkendt og ikke anonyme; det forbedrede atmosfxren og gav større tryghed; og det bidrog til bedre dialog og øget socialisering.
\end{abstract}

\begin{abstract}
Indledning
I folkeskolen, gymnasiet og på seminarierne ville det være uhørt, at lærerne ikke kan alle elevernes navne kort tid efter skoleårets start (Wiberg, 2011). Dette gælder også klasser, hvor læreren kun har klassen i én time om ugen (Schmidt, 2011). Det er endda ikke ualmindeligt, at læreren har lært elevernes navne før første undervisning ved at have øvet sig på klassebilledet fra det foregående år (Vadstrup, 2011).

Sådan er det sjældent på universiteterne, hvor mange lærere efterhånden lærer navnene på en håndfuld af de mest aktive studerende: De som svarer på spørgsmål, stiller uddybende spørgsmål og opsøger læreren i pauserne. Min erfaring er, at mange lærere synes, dette er lidt pinligt. Så mange lærere vil gerne mestre de studerendes navne, men det synes helt uoverkommeligt.

Jeg har gennem årene gjort en indsats for at lære de studerendes navne. Dette har efterhånden krystalliseret sig til en metode, som er så afrundet, at den kan kommunikeres til andre.

Metoden består af otte trin, som beskrives så detaljeret i det følgende, at den burde kunne følges af en motiveret læser. Metoden er helt lavpraktisk og udviklet gennem praksis, men den bygger på anerkendt pædagogisk teori, herom senere. Den ligger
\end{abstract}


også tæt op ad praktisk orienteret litteratur om hukommelse (fx Higbee, 2001), men den er langt mere specifik og derfor lettere at gå til.

Min erfaring viser, at indsatsen klart står mål med udbyttet, primært fordi undervisningsmiljøet bliver langt mere trygt. Dette blev bekræftet af en undersøgelse blandt de studerende: De føler sig anerkendt og velkomne, ligesom det giver større tryghed og medfører større socialisering, idet de studerende anspores til at lære hinandens navne.

\section{Trin 1: Lav en liste over de studerendes navne}

Første trin består i at hente listen med deltagernes navne, fx fra kursuswebsiden, og alfabetisere den efter fornavn. Jeg arkiverer listen i min Filofax og min bærbare computer. Ideen er at have den lige ved hånden, så jeg kan øve mig når som helst og hvor som helst. Dette trin ligger cirka 2 uger før kursusstart.

\section{Trin 2: Øv navnene ... igen og igen}

Jeg lærer nu navnene udenad gennem et antal sessioner. I første session tager jeg listen med navne og skriver dem langsomt af ét for ét i alfabetisk rækkefølge i kolonner på et blankt A4 ark. Jeg memorerer navnene, "tygger" på dem og noterer mig pudsige sammenhænge: Ingen med A, B og C; fire studerende med "Ma..": Magnus, Malene, Marie, Martin; to Jonas og to Sebastian. Kolonnerne er vigtige da de understøtter "chunking" af navnene. Antallet af kolonner afhænger af antallet af studerende; jeg skriver typisk 10-15 navne i hver kolonne. Jeg lægger især mærke til første og sidste navn i hver kolonne; når de sidder fast, er det lettere at komme i gang med de øvrige navne.

I de efterfølgende sessioner genkalder jeg mig navnene og skriver dem på et blankt stykke A4-ark (free recall). Jeg starter typisk med toppen eller bunden af kolonnerne. Som cues anvender jeg dels de navne, der forekommer flere gange, og dels mønstrene, fx de fire "Ma..". Når jeg ikke kan komme på flere navne, tæller jeg de skrevne navne. Hvis der mangler nogle, finder jeg dem på "facitlisten" og skriver dem på arket på "deres plads". Jeg markerer dem og øver dem. Jeg noterer også antallet af manglende navne, så jeg kan se udviklingen fra session til session. Sessionerne kan ligge lige efter hinanden, på samme dag eller med en eller to dages mellemrum; der bør ikke være alt for længe mellem dem. Dette trin ligger typisk i den sidste uge før kursusstart. Målet er at kunne alle navnene den første undervisningsgang.

\section{Trin 3: Skab ejerskab første undervisningsgang}

Ved den første undervisningsgang præsenterer og motiverer jeg mit forehavende. Jeg sørger for, at alle studerende siger deres navn, når de siger noget, og at alle kommer til orde. En mulighed er at tage en systematisk navnerunde for at starte pro- 
cessen med at knytte navne og ansigter sammen. Det er vigtigt at få de studerende til at tage ejerskab og acceptere det sensitive aspekt af metoden. Muligheden for, at jeg ikke kan huske netop deres navn, ligger lige for og er ikke rar for nogen af parterne. Min erfaring viser, at på trods af den forudgående rene udenadslære oplever jeg i dette trin en vis genkendelse: "Aha, du er Marie ... sådan ser de to Jonas'er ud."

\section{Trin 4: Tag billeder af de studerende ${ }^{1}$}

Jeg tager et billede af alle studerende i vilkårlig rækkefølge første undervisningsgang i en pause. For at være sikker på, at der er synkroni mellem billeder og navne, bruger jeg følgende teknik: Før undervisningen laver jeg en A4-side med numre 1, 2, 3, ... op til antallet af tilmeldte. Jeg laver en skillelinje med teksten FOTO mellem nr. 10 og 11, mellem nr. 20 og 21, osv., se figuren. Ved fotograferingen får jeg en studerende til at skrive de studerendes fornavne og evt. første bogstav i efternavnet i den rækkefølge billeder-
6. PERER H
7. MICHAELN
8. BRIAN
9. VIBEKE
10. $J A C O B$
FOTO
11. ANDRE
12. TRINE ne tages. Efter hver 10. studerende tager jeg et billede af navnelisten (ud for FOTO) for at sikre synkroni mellem billeder og navne.

Jeg benytter også lejligheden til at tage billeder af de studerende set fra lærerpositionen, da dette supplerer læringen af forbindelsen mellem navne og ansigter i trin 7.

\section{Trin 5: Lav et billedgalleri}

Jeg laver en mini-udgave på ca. $4 * 6 \mathrm{~cm}$ (ca. $32 \mathrm{~K})$ af hvert billede ved hjælp af computerens billedprogram. Disse små billeder sætter jeg ind i alfabetisk orden i et Word-dokument med tre søjler med navnene under billederne, se figuren. Den beskedne billedopløsning på $32 \mathrm{~K}$ er fuldt tilstrækkeligt til at sikre skarphed og at Word-dokumentet ikke bliver for stort og uhåndterbart.

Jeg printer billedgalleriet i farver og klipper derefter billederne ud enkeltvis. Jeg beholder enten navnet lige under bil-

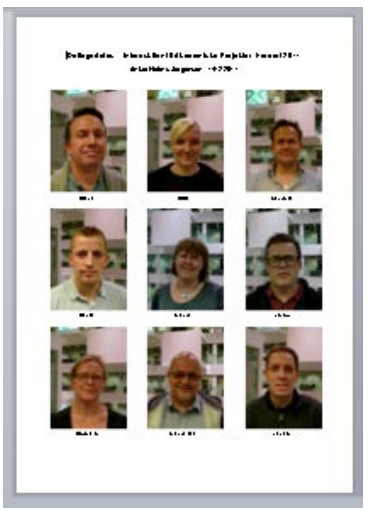
ledet eller klipper det af og skriver det bag på billedet.

\footnotetext{
${ }^{1}$ I modsætning til folkeskolen, gymnasier og seminarier har universiteterne ikke en fast klassestruktur, hvor der foreligger klassebilleder år for år, som læreren kan anvende til at lære elevernes navne.
} 
Trin 6: Gør billedgalleriet tilgængeligt for de studerende

Jeg gør billedgalleriet tilgængeligt for de studerende ved at uploade det på kursuswebsiden for at give dem bedre muligheder for at lære hinandens navne.

Trin 7: Kobl navne og ansigter

I dette trin arbejder jeg med navnene, typisk med udgangspunkt i billedet, da det svarer til praksis: Man ser et ansigt og skal genkalde sig navnet. En måde er at gå billederne igennem et for et og genkalde sig den studerendes navn; jeg siger det gerne højt eller i det mindste "højt inde i hovedet". Hvis jeg er i tvivl, noterer jeg navnet og vedkommendes særlige træk. Jeg blander så billederne og prøver igen.

En anden måde er at genkalde sig hvordan de studerende ser ud. Hvis jeg er sikker: "Jonas ... krøllet, vinduesrækken, snakker meget", så går jeg videre. Hvis jeg er usikker: "Martin ... er det en af de høje, kortklippede fyre?", så finder jeg billedet og øver forbindelsen mellem navn og ansigt. Hvis jeg har svært ved at lære en gruppe, fx de korthårede fyre uden briller, lægger jeg billederne til side og arbejder med disse studerendes kendetegn.

En tredje måde er at lægge alle billederne ud på et bord og lave tilfældige nedslag i den alfabetiske navneliste og udpege den studerendes billede på bordet.

Trin 8: Praktiser og insister!

Det sidste og meget vigtige trin er at praktisere det - og gøre det helt fra starten af anden undervisningsgang. Det fundamentale er, at jeg nævner navnet hver gang en studerende siger noget. Så jeg gør det til en vane, at de studerende markerer når de vil sige noget. Jeg peger på den markerende studerende og siger vedkommendes navn; hvis flere markerer laver jeg en mundtlig talerliste: "Jonas, derefter Katrine og Sebastian." Hvis jeg tøver med et navn, viser erfaringen, at de studerende er meget tilbøjelige til at sige deres navn. Men jeg standser dem, idet jeg insisterer på selv at sige det, også selv om det føles pinligt. Og skulle det ske, at navnet slet ikke dukker op, så beklager jeg det og bruger de andre studerende som ressource: "Hvad er det nu ... hedder?" Herved understøtter jeg, at de studerende lærer hinandens navne og, at de kan vise, at de kan noget, læreren ikke kan.

Der kan være mange årsager til, at et navn ikke dukker op, eller at jeg siger et forkert navn: Måske er billedet af den studerende ikke særligt godt, måske er der tre studerende, der ligner hinanden meget, måske er der tre navne, der minder meget om hinanden og endelig kan en studerende ligne en studerende fra et tidligere semester, hvis navn dukker op først.

I semesterets første uger øver jeg mig ved at gå tilbage til trin 7 og arbejde med billederne, hvor jeg også inddrager billederne af de studerende set fra lærerpositionen. 
Kronen på værket er, når navnene flyder helt frit i undervisningen. Min erfaring er, at det sker ved anden undervisningsgang.

\section{Erfaringer}

\section{Tidsforbrug}

Efterhånden har jeg fået metoden skærpet, så opgaven er overkommelig - ja ligefrem fornøjelig. I sidste semester anvendte jeg metoden i kurset Introduktion til Akademiske Projekter for diplomstuderende med 30 deltagere. I tabellen herunder ses den tid jeg anvendte på de tidskrævende trin uden for undervisningen.

\begin{tabular}{|c|c|c|c|}
\hline Trin & $\begin{array}{c}\text { Trin 1-2 } \\
\text { Lær navnene } \\
\text { udenad }\end{array}$ & $\begin{array}{c}\text { Trin 5 } \\
\text { Lav et } \\
\text { billedgalleri }\end{array}$ & $\begin{array}{c}\text { Trin 7 } \\
\text { Kobl navne } \\
\text { og ansigter }\end{array}$ \\
\hline $\begin{array}{c}\text { Minutter } \\
\text { anvendt }\end{array}$ & $25 \mathrm{~min}$ & $35 \mathrm{~min}$ & $30 \mathrm{~min}$ \\
\hline
\end{tabular}

Tidsforbrug $i$ trinnene uden for undervisningen

Den samlede tid var således 1.5 time ved dette kursus; ${ }^{2}$ dette svarer til 3 minutter pr. studerende og 6 minutter pr. uge i et semester på 15 uger. Jeg anvendte 173 timer til kurset i alt, dvs. de 1.5 time udgør knap $1 \%$ af den samlede tid.

I trin 2 var antallet af manglende navne de første seks gange, jeg skrev navnene på et blankt A4-ark: 5, 0, 0, 0, 0, 0. Så med træning i metoden kan dette trin faktisk være ganske fornøjeligt.

\section{Placering i lokalet}

Jeg har observeret, at de studerendes placering i undervisningslokalet ${ }^{3}$ betyder næsten lige så meget for mig som deres udseende: Katrine sidder konsekvent ved vinduet på første række og Martin sidder altid på bagerste række. Deres påklædning har også meget stor betydning for min læring. Så jeg joker ofte med, at de kan støtte mig i at lære deres navne ved at sidde samme sted i lokalet og have det samme tøj på.

\section{Følsomhed}

Denne tilgang til at lære de studerendes navne kræver en vis portion dristighed, da vores navne er personlige og følsomme, ikke mindst i lyset af magtforholdet mellem lærer og studerende. En studerende vil sandsynligvis opleve det som et nederlag, at

\footnotetext{
${ }^{2}$ Bemærk, at jeg ikke medregner den tid jeg bruger i selve undervisningen, da det er en helt integreret aktivitet og ikke koster ekstra tid.

${ }^{3}$ Det synes også almindeligt, at lærerne i folkeskolen og gymnasiet beder eleverne om at sætte sig samme sted i lokalet de første gange for at skabe et "klassespejl" (Wiberg, 2011).
} 
jeg som lærer tøver eller ikke kan huske vedkommendes navn. Typisk vil jeg kommentere på denne situation på én af to måder. Jeg nævner, at det er lettest at lære navnene på de studerede, der er mest aktive og taler meget. Det er jo fint at tale meget - undervisningen ville være ret kedelig, hvis ingen studerende talte - men det viser sig ofte, at de mere tilbageholdende studerende er blandt dem, der har mest at byde på.

\section{Teoretisk forankring}

Metoden kan forankres i en stor mængde litteratur inden for pædagogisk teori og kognition, specielt ansigtsgenkendelse og hukommelse (Baddeley, 1982; Higbee, 2001). Lad mig helt overordnet bemærke, at grundideen i metoden er skrivning og feedback, som er fundamentale principper i teorier om læring (fx Dysthe et al., 2001), og det kognitionspsykologiske begreb genkaldelse (free recall), som er sværere end genkendelse (recognition), men også resulterer i dybere forankret læring (Colman, 2001, s. 620). Genkaldelsen og skrivningen praktiseres gennem at skrive de studerendes navne igen og igen, mens feedbacken opnås gennem at checke navnene mod "facitlisten" og gennem de studerendes reaktioner i undervisningen. Mere specifikt kan metoden forankres i den pædagogiske teori "den autentiske lærer" (Cranton, 2001; Laursen, 2004). Blandt denne teoris grundprincipper kan nævnes:

- Tydeliggør dine visoner

Dette tydeliggøres gennem at annoncere en måske urealistisk vision om at lære alle de studerendes navne og så gennemføre den.

- Være sikker på, at dine ord og handlinger stemmer overens og vær parat til at indrømme dine fejl

Ved offentligt at vise min egen fejlbarlighed mht. at lære de studerendes navne fremmer jeg accepten af at fejle.

- Vis noget af dig selv som person Dette synes opfyldt, ikke mindst fordi baggrunden er "billig": At stort set ingen andre universitetslærere synes at gøre noget tilsvarende.

- Vis at du tager eleverne alvorligt Vores navne er et fundamentalt aspekt af vores personlighed, hvorfor det at lære andre menneskers navne er at tage dem alvorligt.

- Lad være med at have favoritter blandt de studerende Dette opfyldes ved at insistere på at lære navnene på alle de studerende i stedet for kun en håndfuld af de mest aktive studerende.

- Vxr bevidst om, at du er rollemodel for eleverne Ved at gennemføre en aktivitet, som ligger inden for centrale akademiske 
værdier såsom respekt, tillid og dristighed mener jeg at kunne inspirere de studerende til at gøre noget tilsvarende.

\section{En empirisk undersøgelse af effekten}

En ting er min egen erfaring, en anden er teori, mens en helt tredje er, hvad de studerende mener. For at få indsigt i dette gennemførte jeg en lille empirisk undersøgelse af de studerendes opfattelse af effekten. Jeg lave et mini-spørgeskema med to spørgsmål:

- Har det nogen betydning, at jeg prøver at lære jeres navne?

- Hvis ja, hvilken betydning har det?

Jeg sendte skemaet pr. email til de 50 diplomstuderende, der fulgte mit kursus Introduktion til Akademiske Projekter i foråret og efteråret 2011 (hhv. 29 og 21). Jeg fik 19 svar (hhv. 8 og 11) - det svarer til $38 \%$. Dette er ikke prangende, men nok til at give en rimelig indikation.

Resultaterne viste en klar positiv overvægt: 55 positive ting og 3 negative ting. Det hyppigste svar var at de studerende føler sig velkomne, anerkendt og ikke anonyme (11). Mange angav, at det forbedrede atmosfæren på holdet og gav større tryghed (9), ligesom det bidrog til øget socialisering (5) og bedre dialog (5). De studerende gav udtryk for, at det vidnede om seriøsitet (4) og engagement fra min side (3), ligesom det gav respekt (3), ikke mindst fordi de studerende ikke er vant til dette.

Disse effekter er næppe overraskende, men der kom andre bemærkelsesværdige ting frem. Først og fremmest er de studerende langt mere tilbøjelige til at lære hinandens navne (6), hvad der bidrager til fællesskabet; en studerende angav ligefrem, at det bidrager til at mindske frafaldet. Tre studerende angav, at de anstrenger sig mere for at nå afleveringerne inden fristen, og at de føler sig mere forpligtede. Ydermere mente en studerende, at det "gør én mere modtagelig over for alt det, vi skal have ind i hovedet. "Allermest bemærkelsesværdig var en kommentar fra en meget reflekterende studerende om, at det var en "live præsentation" af værdien af at anvende en metode systematisk, som er en helt fundamental akademisk hjørnesten - en usædvanlig transfer.

Der var imidlertid også ting, der generede eller undrede: Det virker distraherende ("navneleg") eller forstyrrende (2) og vækker undren over, hvorfor dette syntes så vigtigt for mig.

Validiteten af den empiriske undersøgelse kan i høj grad anfægtes, idet jeg har tre roller over for de studerende: 1) Jeg er deres lærer og skal bedømme deres præstatio- 
ner, 2) jeg er udvikler af metoden, og 3) jeg står for undersøgelsen. Men resultaterne synes at give en rimelig entydig indikation og de stemmer godt overens med min egen erfaring. De studerende er voksne mennesker med en professionel baggrund og siger normalt deres mening helt åbent. Således opgiver stort set alle deres navne hvilket er frivilligt - ved de skriftlige evalueringer undervejs i kurset.

\section{Diskussion}

Der er en meget stor individuel variation i menneskers evne til at huske navne og ansigter (Woodhead \& Baddeley, 1981; Higbee, 2001). Så mine konkrete resultater med at lære de studerendes navne kan ikke generaliseres. Og eftersom min performance er et resultat af flere års arbejde med metoden kan andre næppe opnå den samme performance straks - men sandsynligvis efter nogen træning.

Eftersom genkendelse af personer næsten altid er baseret på genkendelse af et ansigt, som man ser, og derpå følgende genkaldelse af navnet, kan min metodes første trin med at lære de studerendes navne udenad diskuteres. Det tager noget tid og kan i sig selv synes overflødigt; men min erfaring viser, at det er med til at give en vis familiaritet med de studerende.

Til sidst kan man med rette spørge om metoden kan bruges til større hold? Jeg har anvendt tidligere varianter af metoden på hold med både 40, 60 og 80 studerende. Og det fungerede, men læringsprocessen tog selvsagt noget mere tid.

\section{Konklusion}

Min metode synes efter flere års udvikling at være rimelig tilgængelig. Metoden synes ret effektiv, idet tidsforbruget ved at lære alle de studerendes navne ved et kursus med 30 studerende som nævnt var 1,5 time, dvs. 3 minutter pr. studerende og 6 minutter pr. uge. At mestre de studerendes navne synes at have en række positive effekter, for eksempel en øget følelse af anerkendelse, større tryghed, øget socialisering, bedre dialog, øget tilbøjelighed til at de studerende lærer hinandens navne og endelig større forpligtelse til at overholde tidsfrister.

\section{Materialer}

På min vejlederblog http://ankervejleder.wordpress.com kan skabeloner for fotolisten og billedgalleriet downloades som Microsoft Word dokumenter.

Anker Helms Jørgensen er lektor på IT Universitetet $i$ København indenfor feltet Human-Computer Interaction. Han har gennem mange år interesseret sig for pædagogik og didaktik, og han har udviklet metoder og metaforer til brug $i$ undervisning og vejledning. Hans vejlederblog kan ses på http://ankervejleder.wordpress.com. 


\section{Referencer}

Baddeley, A. (1982). Your Memory: A Users's Guide. London: Penguin Books.

Colman, A. M. (2001). A Dictionary of Psychology. Oxford: Oxford Unversity Press.

Cranton, P. (2001). Becoming an Authentic Teacher in Higher Education. Malabar, Florida: Krieger Publishing Company.

Dysthe, O., Hertzberg, F., \& Hoel, T. L. (2001). Skrive for at lære. Århus: Klim.

Higbee, K. (2001). Your Memory - How it Works and How to Improve It. Perseus Books.

Laursen, P. F. (2004). Den autentiske lærer. København: Gyldendal.

Schmidt, S. (2011). Personlig email-korrepondance 20/6 2011.

Vadstrup, I. (2011). Personlig email-korrepondance 20/6 2011.

Wiberg, M. (2011): Personlig email-korrepondance 22/6 2011.

Woodhead, M. M., \& Baddeley, A. (1981). "Individual differences and memory for faces, pictures, and words", in Memory and Cognition, vol 9, nr. 4, 368-370. 